THE CONFLICT OVER THE CONFLICT 


\section{OTHER BOOKS BY KENNETH S. STERN}

Holocaust Denial (1993)

Loud Hawk: The United States versus the American Indian Movement (1994)

A Force upon the Plain: The American Militia Movement and the Politics of Hate (1996)

Antisemitism Today: How It Is the Same, How It Is Different, and How to Fight It (2006) 


\title{
THE CONFLICT OVER THE CONFLICT
}

The Israel/Palestine Campus Debate

\author{
Kenneth S. Stern
}

Foreword by Nadine Strossen

NEW JEWISH PRESS

an imprint of University of Toronto Press

Toronto Buffalo London 
(c) Kenneth S. Stern 2020

Published by New Jewish Press

an imprint of University of Toronto Press

Toronto Buffalo London

utorontopress.com

Printed in Canada

ISBN 978-1-4875-0736-7 (cloth) ISBN 978-1-4875-3610-7 (EPUB)

ISBN 978-1-4875-3609-1 (PDF)

\section{Library and Archives Canada Cataloguing in Publication}

Title: The conflict over the conflict : the Israel/Palestine campus debate /

Kenneth S. Stern ; foreword by Nadine Strossen.

Names: Stern, Kenneth S. (Kenneth Saul), 1953-, author.

Description: Includes bibliographical references and index.

Identifiers: Canadiana (print) 20200156780 | Canadiana

(ebook) 20200156845 | ISBN 9781487507367 (cloth) |

ISBN 9781487536107 (EPUB) | ISBN 9781487536091 (PDF)

Subjects: LCSH: Academic freedom. | LCSH: Freedom of speech. |

LCSH: Education, Higher - Political aspects. | LCSH: Arab-

Israeli conflict.

Classification: LCC LC72 .S74 2020 | DDC 378.1/213 - dc23

University of Toronto Press acknowledges the financial assistance to its publishing program of the Canada Council for the Arts and the Ontario Arts Council, an agency of the Government of Ontario.

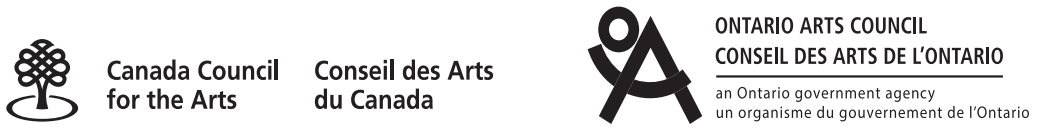

$\begin{array}{r}\text { Funded by the } \\ \text { Government } \\ \text { of Canada }\end{array} \begin{array}{r}\text { Founcernement } \\ \text { du Canada }\end{array}$ 
To the late Thomas Emerson, whose seminal work, The System of Freedom of Expression, is even more relevant today.

To the late James O. Freedman, former president of Dartmouth College - a mensch, a friend, who taught me that the only way to combat bigotry on campus is with methods that uphold, and ideally strengthen, academic freedom.

And to the late Gary Rubin - the smartest, wisest, and kindest Jewish communal professional I had the privilege to know. 
This page intentionally left blank 